\title{
Satisfaction with Social Contacts of Older Europeans
}

\author{
Eric Bonsang • Arthur van Soest
}

Accepted: 26 May 2011/Published online: 15 June 2011

(C) The Author(s) 2011. This article is published with open access at Springerlink.com

\begin{abstract}
This paper analyses the determinants of an important component of well-being among individuals aged 50 years or older in eleven European countries: satisfaction with social contacts. We use data from the Survey of Health, Ageing and Retirement in Europe and anchoring vignettes to correct for potential differences in responses scales across countries and socio-demographic groups. On average, older Europeans report being satisfied with their social contacts, but there exist substantial differences across countries: respondents from Northern countries tend to be more satisfied than individuals from Central or Mediterranean countries. Our analysis shows that correcting for response scale differentials alters the country ranking for of satisfaction with social contacts, while it has much less effect on the estimates of what drives within country determinants.
\end{abstract}

Keywords Anchoring vignettes $\cdot$ Response scale differences $\cdot$ Ageing

JEL Classification $\mathrm{I} 30 \cdot \mathrm{J} 30$

\section{Introduction}

The quality of life of older individuals has become a core topic in economics and social sciences (see, e.g., Motel-Klingebiel et al. 2004). Quality of life can be seen as an aggregation of quality of several domains of life, such as economic welfare or financial situation, health, social contacts and family life, quality of work or other daily activities, etc. (see, e.g., Van Praag et al. 2003; Rojas 2006).

The measurement of well-being and its domains and the ability to compare measurements across populations and socio-economic groups is important for designing and evaluating economic and social policies. For a long time, researchers in the social sciences

E. Bonsang $(\bowtie)$

ROA, Maastricht University, Netspar and Meteor, Maastricht, Netherlands

e-mail: e.bonsang@maastrichtuniversity.nl

A. van Soest

Netspar, Tilburg University, Tilburg, Netherlands

e-mail: avas@uvt.nl 
have extensively used self reported well-being to assess individual well-being. A large number of studies have shown that such measures are useful and contain relevant information to measure actual well-being (cf., e.g., Van Praag and Ferrer-i-Carbonell 2008, or Helliwell et al. 2010). However, even if we may argue that individuals having similar backgrounds, values, and judgments are likely to report subjective well-being in a comparable way, comparability requires much stronger assumptions once we attempt to compare well-being across different cultures and nations.

In this paper we analyze one domain of quality of life of older Europeans: social contacts and family life. This domain has been shown to be important for overall wellbeing in general adult populations in numerous studies. These include studies that view social contacts and family contacts as an individual component of social capital and emphasize the importance of social capital for well-being, both at the individual and at the country level. Helliwell and Putnam (2004), for example, show that good contacts with family, friends, and neighbours are positively associated with life satisfaction or happiness and, in the US, also with health status. Powdthavee (2008) explains life satisfaction of the adult population in the UK from income and objective measures of the number of contacts with friends, relatives and neighbours and uses the results to compute a shadow price of social contacts. He finds that an increase in the level of social involvements can be worth up to an extra $£ 85,000$ a year in terms of life satisfaction.

Another line of studies explains satisfaction with life from satisfaction with domains of life also find a large role for social contacts; see, e.g., Rojas (2006) for the effect of satisfaction with family relations for life satisfaction in Mexico, González et al. (2007) for the importance of satisfaction with friends for life satisfaction of adolescents in Catalonia (N.E. of Spain), or Van Praag and Ferrer-i-Carbonell (2008, p. 91) who find a positive and significant effect of satisfaction with social life on life satisfaction in the UK which is larger than the effect of any other domain in their analysis, including financial satisfaction or health satisfaction. A similar result is reported by Kapteyn et al. (2010, p. 77) who find that both in the US and in the Netherlands, satisfaction with social contacts contributes more to satisfaction with life than satisfaction with income, health satisfaction, and satisfaction with work or daily activities. There is some evidence that satisfaction with social contacts also affects behaviour. Frijters (2000) finds that Russians who are less satisfied with their marriage more often have intentions to change their family situation. Melchior et al. (2003) find a substantial negative effect of satisfaction with social relations on days of sickness absence from work, even though they also control for indexes of social networks and social support of work (which also have significant negative effects on sick days and are correlated with social relations).

The domain of social contacts has been shown to be particularly relevant for older populations. A meaningful social network protects against loneliness and social isolation (Holmén and Furukowa 2002). Wang et al. (2002) demonstrate that a rich social network reduces the risk of future dementia and Rasulo et al. (2005) find that having close ties with friends has a positive effect on length of life. Pollack and Von dem Knesebeck (2004) show that social participation together with other aspects of social capital (trust and reciprocity) is positively associated with health among the populations of 60 years and older in the US and Germany. Good social relationships are also commonly mentioned as constituents of quality of life in open-ended interview questions (see Farquhar 1995; Gabriel and Bowling 2004). Findlay (2003) emphasizes the importance of combating social isolation of older people and discusses the efficiency of interventions to improve social contacts such as discussion groups, community service provision, and stimulating Internet usage.

In this paper, we focus on explaining satisfaction with social contacts among individuals of ages 50 and older in 11 European countries. We analyze its determinants at the 
individual level, but are particularly interested in the cross-country differences and international comparability. The main novelty compared to existing studies explaining satisfaction with social contacts is that we enhance comparability exploiting anchoring vignettes to correct for differences in response scales across countries and socio-economic groups, following the methodology introduced by King et al. (2004): respondents are not only asked to evaluate their own social contacts, but also those of so-called anchoring vignettes-hypothetical individuals whose social contacts are presented to the respondents in short descriptions. Systematic differences in the evaluations of the same hypothetical individuals by respondents in different cultures or socio-economic groups are used to identify systematic differences in response scales. Similar studies have been performed for other important domains of quality of life. See, e.g., Bago d'Uva et al. (2008) on health, King et al. (2004) on health and political efficacy, Kapteyn et al. (2007) on work disability, Kristensen and Johansson (2008) on job satisfaction, Rice et al. (2010) on health system performance, and Kapteyn et al. (2010) on life satisfaction. A common conclusion of these studies is that cultural differences across countries lead to differences in ways people in different countries use subjective response scales like "very satisfied", "satisfied", etc., and that correcting for such differences changes the substantive conclusions about differences in these domains of well-being across countries. The domain of social contacts we consider here has to our knowledge not yet been analyzed in this way.

Section 2 explains the methodology of using anchoring vignettes to correct for differences in response scales and provides a brief description of the empirical model developed by King et al. (2004). Section 3 presents the data and the variables used in the model and Section 4 presents estimation results. In Section 5, we present counterfactuals describing the distribution of satisfaction with social contacts if individuals from all countries were using the same response scales (i.e., the response scales of Germany). Our main finding here is that correcting for response scale differences changes the ranking across countries of average satisfaction with social contacts, while it has little impact on the estimated effects of socio-demographic factors, time use, and social participation. Section 6 concludes.

\section{The Model}

The anchoring vignette methodology was first introduced by King et al. (2004) to measure subjective ordinal responses taking into account differences in the reporting styles across individuals. The ordinal nature of self-reported satisfaction (with social contacts, in our case) $s_{i}$ is taken into account using an ordered response model: we define a latent satisfaction variable $\left(s_{i}^{*}\right)$ as:

$$
s_{i}^{*}=X_{i} \beta+\varepsilon_{i},
$$

where $X_{i}$ is a vector of explanatory variables including country dummies, gender, years of education, etc., and $\beta$ is a vector of unknown parameters. The error term $\varepsilon_{i}$ is assumed to follow a standard normal distribution, independent of $X_{i}$. Reported satisfaction $\left(s_{i}\right)$ is a categorical variable based upon the latent $s_{i}^{*}$ :

$$
s_{i}=j \quad \text { if } \quad \tau_{i}^{j-1}<s_{i}^{*} \leq \tau_{i}^{j},
$$

If the thresholds between categories are the same for all respondents $\left(\tau_{i}^{j}=\tau^{j}\right.$ for all $i, j$ ) then this gives the standard ordered probit model for ordered categorical outcomes. The 
distinguishing feature of the current model is that the thresholds are allowed to vary with observed respondent characteristics in the following way:

$$
\begin{aligned}
\tau_{i}^{1} & =X_{i} \gamma^{1}, \\
\tau_{i}^{j} & =\tau_{i}^{j-1}+\exp \left(X_{i} \gamma^{j}\right), \quad j=2,3,4 .
\end{aligned}
$$

Here the $\gamma^{j}, j=1,2,3,4$, are vectors of unknown parameters. To identify $\beta, \gamma^{1}, \ldots, \gamma^{4}$, additional information is used in the form of vignette evaluations $V_{i}^{k}(k=1, \ldots, K)$, where $K$ is the number of different vignettes evaluated by the respondents. These are modelled as follows:

$$
\begin{aligned}
V_{i}^{* k} & =\theta^{k}+v_{i}^{k}, \\
V_{i}^{k} & =j \quad \text { if } \quad \tau_{i}^{j-1}<V_{i}^{* k} \leq \tau_{i}^{j},
\end{aligned}
$$

where $V_{i}^{k}$ is the evaluation of vignette $k$ by respondent $i, \theta^{k}$ is the underlying satisfaction level associated to the hypothetical person described by the vignette $k$, and $v_{i}^{k}$ is the error term, assumed to be normally distributed with mean 0 and variance $\sigma_{v}^{2}$, with $v_{i}^{k}$, $k=1, \ldots, K$, independent of each other, of $\varepsilon_{i}$, and of $X_{i}$.

There are two main identifying assumptions underlying this model. The first is "response consistency": a given respondent uses the same scales $\tau_{i}^{j}$ for self-reports and vignettes evaluations. King et al. (2004) and Van Soest et al. (2011) have provided evidences supporting this hypothesis for vignettes on vision and drinking behaviour, by comparing vignette corrected self-reports and objective measures. The second assumption is "vignette equivalence": there should be no systematic differences in the interpretation of a given vignette between respondents with different characteristics $X_{i}$ (so that $V_{i}^{* k}$ does not vary with $X_{i}$ ).

We are not aware of any formal tests of the vignette equivalence assumption. In principle, it requires that the vignettes completely describe the domain they refer to, that is, in our case, the quality of the hypothetical's individual's social contacts. Otherwise, respondents with different backgrounds may impute the missing information in their own ways based upon their own experiences, possibly leading to systematic differences in the way the vignette is interpreted. If the vignette descriptions are indeed unambiguous, differences in evaluations will not reflect differences in how respondents interpret the vignettes but differences in the response scales they use-which is essentially why the vignettes can be used to correct for response scale differences.

In practice, there will be a trade off between completeness of the vignette description and the length of the vignette-respondents are likely to read less carefully and evaluate less precisely if vignette descriptions become too long. By capturing the main features of social contacts in the vignettes, the hope is that vignette equivalence is approximately satisfied, so that the corrections for response scale differences may not be perfect but are a substantial improvement compared to the raw, uncorrected, evaluations.

\section{Data}

\subsection{The Sample}

The empirical analysis is based on data from the COMPARE sample which is part of the second wave (2006-2007) of the Survey of Health, Ageing and Retirement in Europe 
(SHARE). SHARE includes extensive survey information on health, employment, financial situation, family and activities of a representative sample of the $50+$ populations in 15 European countries (Börsch-Supan et al. 2005, 2008). The COMPARE sample consists of random subsamples of the complete SHARE samples in 11 countries. Respondents in these subsamples did the complete face to face SHARE interview, and were then asked to complete a drop-off questionnaire with self-assessment evaluations on satisfaction with different domains of life and to evaluate satisfaction with the same domains of life for hypothetical individuals described in the survey questions (the vignettes); see Van Soest (2008). SHARE respondents in the other subsamples got a completely different drop-off questionnaire. Response rates to the main survey and the drop-off were similar for the COMPARE sample and the remaining SHARE sample. The COMPARE sample includes 7,509 individuals aged 50+ from eleven European countries: Belgium, Czech Republic, Denmark, France, Germany, Greece, Italy, the Netherlands, Poland, Spain, and Sweden. Among them, 7,294 respondents answered the questions about satisfaction with social contacts and the corresponding vignettes. After discarding 295 observations with missing or unreliable values for the explanatory variables used in the analysis, our final sample includes 6,999 individuals. ${ }^{1}$

\subsection{Self-Assessment and Vignettes}

Satisfaction with social contacts is measured using the following question:

\section{Self-assessment:}

How satisfied are you with your social contacts (with family, friends, etc.)?

Very dissatisfied/Dissatisfied/Neither satisfied, nor dissatisfied/Satisfied/Very satisfied

After the self-evaluation on satisfaction with social contacts, the respondents were asked to report the satisfaction with social contacts of individuals facing a hypothetical situation. These vignettes are formulated as follows:

\section{Vignette 1:}

John is single, but gets on well with his relatives and has a large circle of friends. They often go out together to attend sporting events or to have a meal. How satisfied do you think John is with his social contacts (family, friends, etc.)? Very dissatisfied/Dissatisfied/Neither satisfied, nor dissatisfied/Satisfied/Very satisfied

\section{Vignette 2:}

Mary has been married for many years. Lately she has spent little time with her husband and they have been quarrelling more. They seem to prefer spending time with others rather than with each other. Both of them have many friends.

How satisfied do you think Mary is with her social contacts (family, friends, etc.)? Very dissatisfied/Dissatisfied/Neither satisfied, nor dissatisfied/Satisfied/Very satisfied

Table 1 shows the distribution of the self-assessments by country, while Tables 2 and 3 present the vignette evaluations. There are substantial differences across countries, both for

\footnotetext{
1 Table 6 in the Appendix compares the means of the main characteristics of our sample with the complete SHARE sample by country. In general, the differences are small and insignificant but there are some exceptions. For example, in some countries, the COMPARE sample is younger than the complete SHARE sample. This is largely due to the fact that the older age groups have a lower probability to complete the drop-off questionnaire with the (self-assessment and vignette) questions of our focus.
} 
Table 1 Distribution of own satisfaction with social contacts among the $50+$ in Europe (in percentage)

\begin{tabular}{llllll}
\hline & $\begin{array}{l}\text { Very } \\
\text { dissatisfied }\end{array}$ & Dissatisfied & $\begin{array}{l}\text { Nor satisfied, } \\
\text { neither dissatisfied }\end{array}$ & Satisfied & $\begin{array}{l}\text { Very } \\
\text { satisfied }\end{array}$ \\
\hline Sweden & 0 & 2 & 13 & 44 & 41 \\
Denmark & 0 & 1 & 7 & 48 & 44 \\
Netherlands & 0 & 2 & 8 & 69 & 20 \\
Germany & 1 & 2 & 12 & 60 & 25 \\
Belgium & 1 & 5 & 14 & 59 & 21 \\
France & 2 & 5 & 15 & 59 & 19 \\
Poland & 1 & 4 & 17 & 59 & 19 \\
Czech Republic & 1 & 4 & 15 & 57 & 23 \\
Italy & 1 & 6 & 16 & 60 & 16 \\
Spain & 1 & 5 & 16 & 60 & 18 \\
Greece & 0 & 9 & 31 & 42 & 18 \\
All & 1 & 4 & 14 & 56 & 25 \\
\hline
\end{tabular}

COMPARE sample. All individuals being 50 years-old or over

the self-assessments and the vignette evaluations. Swedish and Danish respondents give the highest self-assessments, while Greece is a clear outlier on the negative side. Dutch respondents very often assess themselves as "satisfied" but hesitate to use the extreme "very satisfied". Surprisingly, this is not at all the case for the vignette evaluations, where the Dutch use "very satisfied" more often than anyone else. As a consequence, correcting for DIF will make the relative lack of "very satisfied" self-assessments in the Netherlands even larger.

\subsection{Explanatory Variables}

In addition to country dummies, the econometric model includes socio-demographic characteristics such as gender, age, marital status and reported years of education. Means by country are given in the "Appendix". Two indicators of health are used in both models: the number of self-reported symptoms of the respondent and the number of chronic diseases. Income is measured by the logarithm of reported monthly net household income last month, adjusted by PPP. ${ }^{2}$ We included several variables related to family ties: the number of children, a dummy for individuals having a co-residing child and the (log of the) number of annual contacts with children. To measure the involvement of the older individuals in non-professional activities, we added a set of dummies related to different types of activities: "Doing voluntary or charity work", "caring for a sick or disabled adult", "providing help to friends or neighbours", "attending an educational or training course", "going to a sport, social or other kind of club", "taking part in activities of a religious organization", and "taking part in a political or community-related organization". In the

\footnotetext{
2 Outliers and missing incomes are imputed using an alternative income measure (last year's income of all household members) as one of the predictor variables. An appendix with details is available upon request from the authors.
} 
Table 2 Distribution of satisfaction with social contacts Vignettes 1 among the 50+ individuals in Europe (in percentage)

\begin{tabular}{llllll}
\hline & $\begin{array}{l}\text { Very } \\
\text { dissatisfied }\end{array}$ & Dissatisfied & $\begin{array}{l}\text { Nor satisfied, } \\
\text { neither dissatisfied }\end{array}$ & Satisfied & $\begin{array}{l}\text { Very } \\
\text { satisfied }\end{array}$ \\
\hline Sweden & 0 & 1 & 6 & 56 & 37 \\
Denmark & 0 & 0 & 5 & 57 & 37 \\
Netherlands & 0 & 0 & 4 & 56 & 40 \\
Germany & 0 & 2 & 7 & 59 & 32 \\
Belgium & 1 & 1 & 7 & 53 & 39 \\
France & 1 & 1 & 9 & 62 & 28 \\
Poland & 0 & 1 & 12 & 56 & 30 \\
Czech Republic & 0 & 1 & 7 & 56 & 36 \\
Italy & 1 & 3 & 13 & 66 & 16 \\
Spain & 0 & 1 & 8 & 59 & 32 \\
Greece & 0 & 5 & 25 & 45 & 25 \\
All & 0 & 1 & 9 & 57 & 33 \\
\hline
\end{tabular}

COMPARE sample. All individuals being 50 years-old or over

Table 3 Distribution of satisfaction with social contacts Vignettes 2 among the 50+ individuals in Europe (in percentage)

\begin{tabular}{lllllc}
\hline & $\begin{array}{l}\text { Very } \\
\text { dissatisfied }\end{array}$ & Dissatisfied & $\begin{array}{l}\text { Nor satisfied, } \\
\text { neither dissatisfied }\end{array}$ & Satisfied & $\begin{array}{l}\text { Very } \\
\text { satisfied }\end{array}$ \\
\hline Sweden & 7 & 58 & 26 & 7 & 1 \\
Denmark & 3 & 25 & 31 & 35 & 7 \\
Netherlands & 1 & 21 & 32 & 34 & 11 \\
Germany & 3 & 41 & 37 & 16 & 2 \\
Belgium & 4 & 40 & 35 & 17 & 3 \\
France & 6 & 48 & 35 & 10 & 1 \\
Poland & 4 & 40 & 35 & 20 & 2 \\
Czech Republic & 6 & 40 & 40 & 13 & 0 \\
Italy & 8 & 49 & 29 & 13 & 1 \\
Spain & 7 & 35 & 23 & 32 & 3 \\
Greece & 12 & 19 & 36 & 27 & 5 \\
All & 5 & 38 & 34 & 21 & 3 \\
\hline COMPARE & (2) & & & & \\
\hline
\end{tabular}

COMPARE sample. All individuals being 50 years-old or over

literature, such activities are seen as an important aspect of social capital (see Helliwell and Putnam 2004), but they can also be a source of social contacts.

\section{Results}

Table 4 presents the parameter estimates on the country dummies for the ordered probit and the hopit model explaining satisfaction with social contacts and family life, for several 


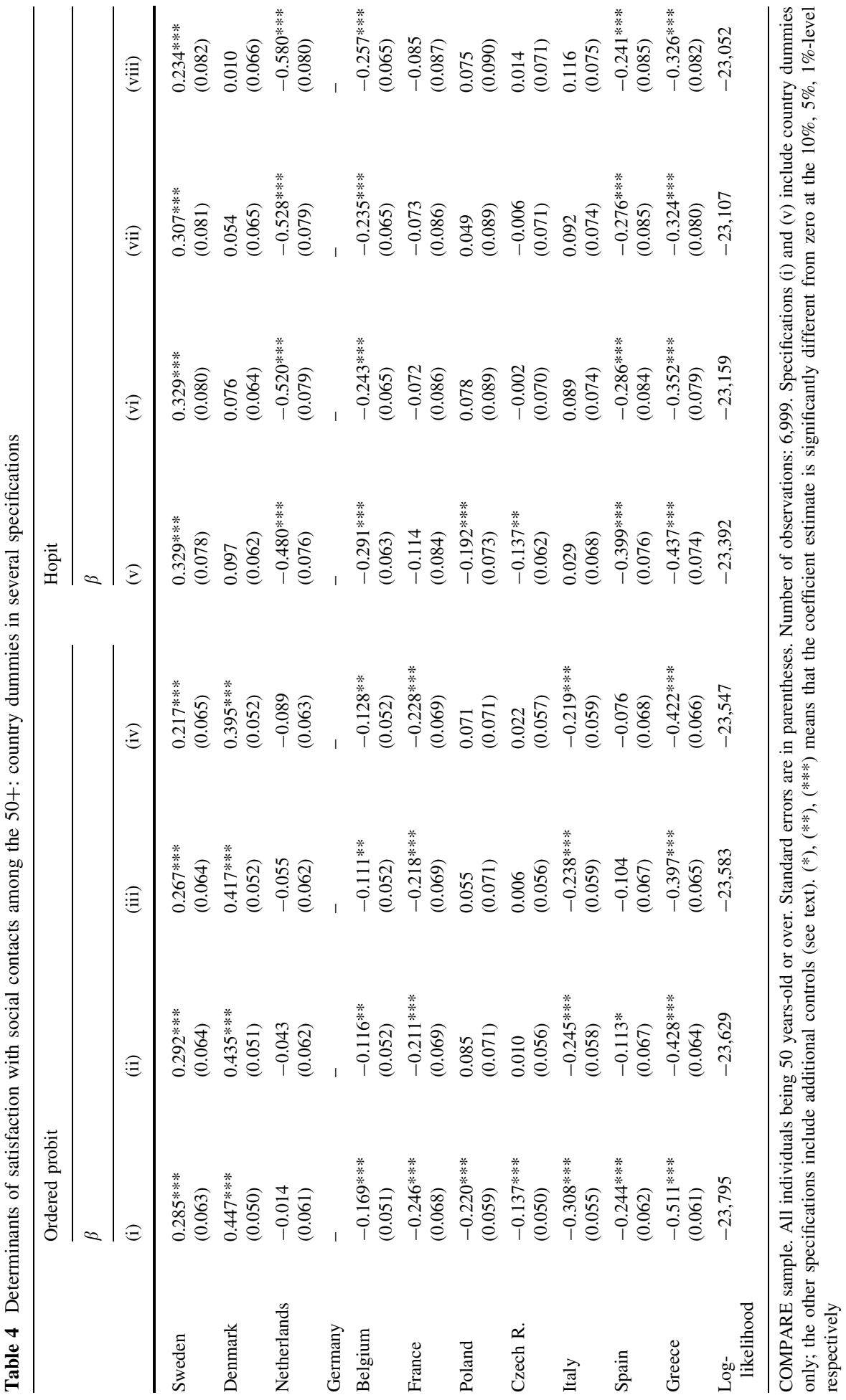


specifications. The coefficients presented in column (i), where the model only includes country dummies as explanatory variables, replicates the large cross-country differences in reported satisfaction levels already apparent from Table 1. Danes and Swedes report the highest satisfaction with social contacts while Greek respondents give the lowest ratings, followed at a respectable distance by France and Italy.

Columns (ii) (iii), (iv) and columns (vi), (vii) and (viii) present the results from the models including additional controls for the ordered probit and the hopit models, respectively. Models (ii) and (vi) include gender, age, years of education, (the log of) household size, (the log of) household income, the number of chronic diseases and the number of symptoms. In Models (iii) and (vii), we also include children-related variables: the number of children, a dummy indicating whether the individual co-resides with one of their children, and the (log of) number of annual contacts with all the children. Finally, Models (iv) and (viii) also include dummies indicating the involvement of the individual in non-professional activities.

Introducing the additional explanatory variables in the simple ordered probit model (columns (ii), (iii), and (iv)) mainly improves the position of the Czech Republic and Poland. This is because respondents in these countries have relatively low income and poor health (see Table 7 in the "Appendix"), two factors that can explain the relatively low satisfaction with social contacts in these countries (see Table 5 and its discussion below). On the other hand, adding the additional controls has little impact on the ranking of the other countries. Greece remains a negative outlier: even when characteristics such as age, income, family composition, and social participation are controlled for Greek respondents still report much less satisfaction with social contacts than the respondents in other countries.

One of the main purposes of our paper is to analyze what happens to the country specific effects when we control for response scale differences. This can be seen by comparing the estimates in the ordered probit model with those in the hopit model for the same specification. The results of the hopit model presented in columns (v), (vi), (vii), and (viii) show that controlling for response style differences changes the cross-country comparison substantially. Irrespective which of the four specifications is considered (that is, irrespective of whether the observed factors driving satisfaction with social contacts are controlled for or not), the highest parameters on the country dummies are found for Sweden. Therefore, the country with the highest satisfaction with social contacts (keeping other factors constant or not) is now Sweden, while Denmark falls back to second place if the other factors are not controlled for column (v), and even farther when other factors are kept constant [columns (vi)-(viii)]. ${ }^{3}$ One striking difference comes from the Netherlands which has the lowest country specific effect score after Greece, while it was in a much better position in each of the simple ordered probit models [columns (i)-(iv)]. Another striking result is Italy, which does much better when the differences in response scales are controlled for. The inclusion of the additional control variables seems to explain part of the difference between Denmark and Germany suggesting that the difference in satisfaction with social contacts between these two countries is partly due to the higher involvement of older individuals in non-professional activities in Denmark. On the other hand, the difference between Germany and the Netherlands is even larger when we control for the

\footnotetext{
${ }^{3}$ Note that since Germany is the benchmark country, its country specific effect is zero by definition.
} 
Table 5 Determinants of satisfaction with social contacts and response styles

\begin{tabular}{|c|c|c|c|c|c|c|}
\hline & \multirow{2}{*}{$\begin{array}{l}\text { Ordered } \\
\text { probit } \\
\beta\end{array}$} & \multicolumn{5}{|l|}{ Hopit } \\
\hline & & $\beta$ & $\gamma_{1}$ & $\gamma_{2}$ & $\gamma_{3}$ & $\gamma_{4}$ \\
\hline Constant & - & - & $\begin{array}{l}-1.109^{*} \\
(0.633)\end{array}$ & $\begin{array}{l}0.095 \\
(0.354)\end{array}$ & $\begin{array}{l}0.098 \\
(0.325)\end{array}$ & $\begin{array}{l}0.313 \\
(0.198)\end{array}$ \\
\hline \multicolumn{7}{|l|}{ Country } \\
\hline Sweden & $\begin{array}{l}0.217 * * * \\
(0.065)\end{array}$ & $\begin{array}{l}0.234^{* * * *} \\
(0.082)\end{array}$ & $\begin{array}{l}0.236^{* *} \\
(0.118)\end{array}$ & $\begin{array}{l}0.084 \\
(0.069)\end{array}$ & $\begin{array}{l}-0.207 * * * \\
(0.072)\end{array}$ & $\begin{array}{l}-0.205^{\text {**** }} \\
(0.043)\end{array}$ \\
\hline Denmark & $\begin{array}{l}0.395 * * * \\
(0.052)\end{array}$ & $\begin{array}{l}0.010 \\
(0.066)\end{array}$ & $\begin{array}{l}-0.101 \\
(0.111)\end{array}$ & $\begin{array}{l}-0.168 * * \\
(0.073)\end{array}$ & $\begin{array}{l}-0.093 \\
(0.057)\end{array}$ & $\begin{array}{l}0.041 \\
(0.031)\end{array}$ \\
\hline Netherlands & $\begin{array}{l}-0.089 \\
(0.063)\end{array}$ & $\begin{array}{l}-0.580 * * * \\
(0.080)\end{array}$ & $\begin{array}{l}-0.355^{* *} \\
(0.153)\end{array}$ & $\begin{array}{l}-0.127 \\
(0.098)\end{array}$ & $\begin{array}{l}-0.069 \\
(0.072)\end{array}$ & $\begin{array}{l}0.122 * * * \\
(0.037)\end{array}$ \\
\hline Germany & - & - & - & - & - & - \\
\hline Belgium & $\begin{array}{l}-0.128^{* *} \\
(0.052)\end{array}$ & $\begin{array}{l}-0.257 * * * \\
(0.065)\end{array}$ & $\begin{array}{l}0.129 \\
(0.098)\end{array}$ & $\begin{array}{l}-0.089 \\
(0.062)\end{array}$ & $\begin{array}{l}-0.098^{*} \\
(0.054)\end{array}$ & $\begin{array}{l}-0.044 \\
(0.033)\end{array}$ \\
\hline France & $\begin{array}{l}-0.228^{* * * *} \\
(0.069)\end{array}$ & $\begin{array}{l}-0.085 \\
(0.087)\end{array}$ & $\begin{array}{l}0.395^{* * *} * \\
(0.119)\end{array}$ & $\begin{array}{l}-0.120 \\
(0.077)\end{array}$ & $\begin{array}{l}-0.063 \\
(0.070)\end{array}$ & $\begin{array}{l}-0.014 \\
(0.043)\end{array}$ \\
\hline Poland & $\begin{array}{l}0.071 \\
(0.071)\end{array}$ & $\begin{array}{l}0.075 \\
(0.090)\end{array}$ & $\begin{array}{l}-0.032 \\
(0.134)\end{array}$ & $\begin{array}{l}0.052 \\
(0.086)\end{array}$ & $\begin{array}{l}-0.062 \\
(0.072)\end{array}$ & $\begin{array}{l}0.027 \\
(0.044)\end{array}$ \\
\hline Czech Republic & $\begin{array}{l}0.022 \\
(0.057)\end{array}$ & $\begin{array}{l}0.014 \\
(0.071)\end{array}$ & $\begin{array}{l}0.192 * \\
(0.103)\end{array}$ & $\begin{array}{l}-0.119 * \\
(0.067)\end{array}$ & $\begin{array}{l}0.008 \\
(0.056)\end{array}$ & $\begin{array}{l}-0.030 \\
(0.035)\end{array}$ \\
\hline Italy & $\begin{array}{l}-0.219 * * * \\
(0.059)\end{array}$ & $\begin{array}{l}0.116 \\
(0.075)\end{array}$ & $\begin{array}{l}0.476^{* * * *} \\
(0.102)\end{array}$ & $\begin{array}{l}-0.039 \\
(0.065)\end{array}$ & $\begin{array}{l}-0.189 * * * \\
(0.061)\end{array}$ & $\begin{array}{l}0.102 * * * \\
(0.036)\end{array}$ \\
\hline Spain & $\begin{array}{r}-0.076 \\
(0.068)\end{array}$ & $\begin{array}{l}-0.241^{* * *} \\
(0.085)\end{array}$ & $\begin{array}{l}0.273 * * \\
(0.118)\end{array}$ & $\begin{array}{l}-0.172 * * \\
(0.082)\end{array}$ & $\begin{array}{l}-0.386^{* * * *} \\
(0.076)\end{array}$ & $\begin{array}{l}0.118^{* * * *} \\
(0.040)\end{array}$ \\
\hline Greece & $\begin{array}{l}-0.422 * * * \\
(0.066)\end{array}$ & $\begin{array}{l}-0.326^{* * *} \\
(0.082)\end{array}$ & $\begin{array}{l}0.672 * * * \\
(0.115)\end{array}$ & $\begin{array}{l}-0.486^{* * * *} \\
(0.094)\end{array}$ & $\begin{array}{l}0.149 * * \\
(0.061)\end{array}$ & $\begin{array}{l}-0.218^{* * * *} \\
(0.045)\end{array}$ \\
\hline Woman & $\begin{array}{l}0.214 * * * \\
(0.030)\end{array}$ & $\begin{array}{l}0.178^{* * * *} \\
(0.037)\end{array}$ & $\begin{array}{l}-0.044 \\
(0.053)\end{array}$ & $\begin{array}{l}0.018 \\
(0.035)\end{array}$ & $\begin{array}{l}0.006 \\
(0.031)\end{array}$ & $\begin{array}{l}-0.027 \\
(0.018)\end{array}$ \\
\hline Age & $\begin{array}{l}0.006 * * * \\
(0.002)\end{array}$ & $\begin{array}{l}0.008^{* * * *} \\
(0.003)\end{array}$ & $\begin{array}{l}0.000 \\
(0.003)\end{array}$ & $\begin{array}{l}-0.001 \\
(0.002)\end{array}$ & $\begin{array}{l}0.005^{* *} \\
(0.002)\end{array}$ & $\begin{array}{l}-0.002 \\
(0.001)\end{array}$ \\
\hline Years of education & $\begin{array}{l}0.009 * * \\
(0.004)\end{array}$ & $\begin{array}{l}0.006 \\
(0.005)\end{array}$ & $\begin{array}{l}-0.017 * * \\
(0.007)\end{array}$ & $\begin{array}{l}0.010^{* * *} \\
(0.005)\end{array}$ & $\begin{array}{l}-0.003 \\
(0.004)\end{array}$ & $\begin{array}{l}0.002 \\
(0.003)\end{array}$ \\
\hline Ln(household size) & $\begin{array}{l}0.068 \\
(0.070)\end{array}$ & $\begin{array}{l}0.150^{*} \\
(0.087)\end{array}$ & $\begin{array}{l}0.102 \\
(0.121)\end{array}$ & $\begin{array}{l}-0.011 \\
(0.084)\end{array}$ & $\begin{array}{l}-0.022 \\
(0.072)\end{array}$ & $\begin{array}{l}0.022 \\
(0.043)\end{array}$ \\
\hline $\begin{array}{l}\text { Ln(household } \\
\text { income) }\end{array}$ & $\begin{array}{l}0.125^{* * * *} \\
(0.040)\end{array}$ & $\begin{array}{l}0.119 * * \\
(0.050)\end{array}$ & $\begin{array}{l}-0.060 \\
(0.066)\end{array}$ & $\begin{array}{l}0.053 \\
(0.043)\end{array}$ & $\begin{array}{l}-0.060 \\
(0.040)\end{array}$ & $\begin{array}{l}0.033 \\
(0.024)\end{array}$ \\
\hline Number of symptoms & $\begin{array}{l}-0.099 * * * \\
(0.009)\end{array}$ & $\begin{array}{l}-0.091 * * * \\
(0.011)\end{array}$ & $\begin{array}{l}0.057 * * * \\
(0.015)\end{array}$ & $\begin{array}{l}-0.025^{* *} \\
(0.010)\end{array}$ & $\begin{array}{l}-0.008 \\
(0.009)\end{array}$ & $\begin{array}{l}-0.011 * \\
(0.006)\end{array}$ \\
\hline $\begin{array}{l}\text { Number of chronic } \\
\text { diseases }\end{array}$ & $\begin{array}{l}0.000 \\
(0.011)\end{array}$ & $\begin{array}{l}0.011 \\
(0.014)\end{array}$ & $\begin{array}{l}-0.047 * * \\
(0.019)\end{array}$ & $\begin{array}{l}0.038^{* * * *} \\
(0.012)\end{array}$ & $\begin{array}{l}0.000 \\
(0.011)\end{array}$ & $\begin{array}{l}0.004 \\
(0.007)\end{array}$ \\
\hline $\begin{array}{l}\text { Living with } \\
\text { a partner }\end{array}$ & $\begin{array}{l}0.105^{*} \\
(0.054)\end{array}$ & $\begin{array}{l}0.075 \\
(0.068)\end{array}$ & $\begin{array}{l}-0.010 \\
(0.096)\end{array}$ & $\begin{array}{l}-0.055 \\
(0.066)\end{array}$ & $\begin{array}{l}0.097 * \\
(0.057)\end{array}$ & $\begin{array}{l}-0.021 \\
(0.034)\end{array}$ \\
\hline Number of children & $\begin{array}{l}-0.011 \\
(0.013)\end{array}$ & $\begin{array}{l}-0.027 * \\
(0.016)\end{array}$ & $\begin{array}{c}-0.004 \\
(0.021)\end{array}$ & $\begin{array}{l}0.002 \\
(0.014)\end{array}$ & $\begin{array}{c}-0.004 \\
(0.013)\end{array}$ & $\begin{array}{l}-0.015^{*} \\
(0.008)\end{array}$ \\
\hline Co-residing with child & $\begin{array}{l}-0.065 \\
(0.051)\end{array}$ & $\begin{array}{l}-0.068 \\
(0.064)\end{array}$ & $\begin{array}{l}-0.133 \\
(0.090)\end{array}$ & $\begin{array}{l}0.017 \\
(0.061)\end{array}$ & $\begin{array}{l}0.097 * \\
(0.052)\end{array}$ & $\begin{array}{l}0.030 \\
(0.031)\end{array}$ \\
\hline $\begin{array}{l}\text { Ln(contacts with } \\
\text { children) }\end{array}$ & $\begin{array}{l}0.061 * * * \\
(0.007)\end{array}$ & $\begin{array}{l}0.070 * * * \\
(0.009)\end{array}$ & $\begin{array}{l}0.011 \\
(0.012)\end{array}$ & $\begin{array}{l}-0.005 \\
(0.008)\end{array}$ & $\begin{array}{l}-0.003 \\
(0.007)\end{array}$ & $\begin{array}{l}0.012 * * * \\
(0.004)\end{array}$ \\
\hline
\end{tabular}


Table 5 continued

\begin{tabular}{|c|c|c|c|c|c|c|}
\hline & \multirow{2}{*}{$\begin{array}{l}\text { Ordered } \\
\text { probit } \\
\beta\end{array}$} & \multicolumn{5}{|l|}{ Hopit } \\
\hline & & $\beta$ & $\gamma_{1}$ & $\gamma_{2}$ & $\gamma_{3}$ & $\gamma_{4}$ \\
\hline \multicolumn{7}{|l|}{ Professional status } \\
\hline Working & - & - & - & - & - & - \\
\hline Retired & $\begin{array}{l}0.062 \\
(0.043)\end{array}$ & $\begin{array}{l}0.060 \\
(0.054)\end{array}$ & $\begin{array}{l}0.060 \\
(0.075)\end{array}$ & $\begin{array}{l}-0.029 \\
(0.048)\end{array}$ & $\begin{array}{l}-0.003 \\
(0.043)\end{array}$ & $\begin{array}{l}-0.002 \\
(0.026)\end{array}$ \\
\hline Unemployed & $\begin{array}{l}-0.133^{*} \\
(0.079)\end{array}$ & $\begin{array}{l}-0.135 \\
(0.099)\end{array}$ & $\begin{array}{l}0.246^{*} \\
(0.134)\end{array}$ & $\begin{array}{l}-0.133 \\
(0.093)\end{array}$ & $\begin{array}{l}-0.043 \\
(0.082)\end{array}$ & $\begin{array}{l}-0.020 \\
(0.049)\end{array}$ \\
\hline Disabled & $\begin{array}{l}-0.071 \\
(0.075)\end{array}$ & $\begin{array}{l}-0.058 \\
(0.093)\end{array}$ & $\begin{array}{l}0.343 * * * \\
(0.121)\end{array}$ & $\begin{array}{l}-0.255^{* * *} \\
(0.091)\end{array}$ & $\begin{array}{l}0.058 \\
(0.075)\end{array}$ & $\begin{array}{l}-0.043 \\
(0.046)\end{array}$ \\
\hline Inactive & $\begin{array}{l}0.010 \\
\quad(0.057)\end{array}$ & $\begin{array}{r}-0.033 \\
(0.072)\end{array}$ & $\begin{array}{l}0.049 \\
(0.097)\end{array}$ & $\begin{array}{l}-0.032 \\
(0.064)\end{array}$ & $\begin{array}{l}0.027 \\
(0.057)\end{array}$ & $\begin{array}{l}-0.075^{* *} \\
(0.035)\end{array}$ \\
\hline \multicolumn{7}{|l|}{ Non-professional activities } \\
\hline Voluntary/charity & $\begin{array}{l}0.027 \\
(0.043)\end{array}$ & $\begin{array}{l}0.069 \\
(0.055)\end{array}$ & $\begin{array}{l}-0.022 \\
(0.082)\end{array}$ & $\begin{array}{l}-0.005 \\
(0.051)\end{array}$ & $\begin{array}{l}0.072 \\
(0.046)\end{array}$ & $\begin{array}{l}0.009 \\
(0.026)\end{array}$ \\
\hline Caring for sick/disabled & $\begin{array}{l}-0.031 \\
(0.053)\end{array}$ & $\begin{array}{l}-0.068 \\
(0.067)\end{array}$ & $\begin{array}{l}-0.313^{* * *} \\
(0.115)\end{array}$ & $\begin{array}{l}0.154 * * \\
(0.065)\end{array}$ & $\begin{array}{l}-0.033 \\
(0.057)\end{array}$ & $\begin{array}{l}0.056^{*} \\
(0.031)\end{array}$ \\
\hline $\begin{array}{l}\text { Helping friends/ } \\
\text { neighbours }\end{array}$ & $\begin{array}{l}0.127 * * * \\
(0.038)\end{array}$ & $\begin{array}{l}0.173 * * * \\
(0.048)\end{array}$ & $\begin{array}{l}-0.081 \\
(0.071)\end{array}$ & $\begin{array}{l}0.045 \\
(0.043)\end{array}$ & $\begin{array}{l}0.039 \\
(0.040)\end{array}$ & $\begin{array}{l}0.020 \\
(0.023)\end{array}$ \\
\hline Education/training & $\begin{array}{l}-0.034 \\
(0.055)\end{array}$ & $\begin{array}{l}-0.012 \\
(0.069)\end{array}$ & $\begin{array}{l}-0.121 \\
(0.109)\end{array}$ & $\begin{array}{l}0.081 \\
(0.062)\end{array}$ & $\begin{array}{l}0.003 \\
(0.059)\end{array}$ & $\begin{array}{l}-0.002 \\
(0.033)\end{array}$ \\
\hline $\begin{array}{l}\text { Going to sport/social } \\
\text { club }\end{array}$ & $\begin{array}{l}0.103 * * * \\
(0.036)\end{array}$ & $\begin{array}{l}0.158 * * * \\
(0.045)\end{array}$ & $\begin{array}{l}-0.022 \\
(0.067)\end{array}$ & $\begin{array}{l}0.069 * \\
(0.041)\end{array}$ & $\begin{array}{l}-0.057 \\
(0.038)\end{array}$ & $\begin{array}{l}0.014 \\
(0.021)\end{array}$ \\
\hline $\begin{array}{l}\text { Attending religious } \\
\text { activities }\end{array}$ & $\begin{array}{l}0.182 * * * \\
(0.046)\end{array}$ & $\begin{array}{l}0.138 * * \\
(0.058)\end{array}$ & $\begin{array}{l}0.104 \\
(0.078)\end{array}$ & $\begin{array}{l}-0.076 \\
(0.053)\end{array}$ & $\begin{array}{l}-0.066 \\
(0.048)\end{array}$ & $\begin{array}{l}0.013 \\
(0.029)\end{array}$ \\
\hline $\begin{array}{l}\text { Taking part to } \\
\text { organizations }\end{array}$ & $\begin{array}{l}0.301 * * * \\
(0.069)\end{array}$ & $\begin{array}{l}0.296^{* * * *} \\
(0.088)\end{array}$ & $\begin{array}{l}-0.020 \\
(0.128)\end{array}$ & $\begin{array}{l}0.030 \\
(0.078)\end{array}$ & $\begin{array}{l}-0.013 \\
(0.074)\end{array}$ & $\begin{array}{l}-0.019 \\
(0.042)\end{array}$ \\
\hline Log-likelihood & $-23,547$ & $-23,052$ & & & & \\
\hline
\end{tabular}

COMPARE sample. Number of observations: 6,999. Standard errors are in parentheses. $(*),(* *),(* * *)$ means that the coefficient estimate is significantly different from zero at the $10 \%, 5 \%, 1 \%$-level respectively

additional control variables than if we do not, suggesting that non-professional activities in the Netherlands help somewhat to bring the average satisfaction level in the Netherlands closer to that in Germany.

Table 5 displays the complete sets of parameter estimates of the most extensive specifications of the ordered probit and hopit models of satisfaction with social contacts [corresponding to columns (iv) and (viii) in Table 4]. Except for the country dummies, most of the results for the main equation (the estimates of $\beta$ ) are qualitatively similar in the two models. Keeping all other factors constant, women are significantly more satisfied with social contacts than men. This is in line with Van Praag and Ferrer-i-Carbonell (2008), who find that women (of all adult ages) in the UK are more satisfied than men with their marriage and their social life, though in the latter case, the gender effect is not significant. The effect of age is positive and significant in both models. This result is in line with Van 
Praag and Ferrer-i-Carbonell (2008) who find a quadratic age pattern of satisfaction with social life with a minimum at 33 years of age, but differ from those of Motel-Klingebiel et al. (2004) who find a negative association between age and satisfaction with social relationships for the general adult (25+) population in five countries. Household income has a significantly positive effect, in line with Palomar Lever (2004) who finds a positive relation between income and satisfaction with children, couple relationship, and the social network for adults of all ages in Mexico.

In both models, the number of reported symptoms of health problems has a strong and significant negative effect on the outcome variable. Contacts with children have a strong and significant positive effect, but co-residing with children does not make a significant difference. Occupational status has no significant effect in either model. On the other hand, non-professional activities play an important role: participating in a sports or social club and taking part in political or community-related organizations has a significant positive effect on satisfaction with social contacts. So does helping friends or neighbors and this effect is much stronger and more significant in the hopit model than in ordered probit. Doing charity or voluntary work, caring for a sick or disabled person, or attending training or educational course has no significant effect on satisfaction with social contacts.

There are a few exceptions of variables that do change in magnitude or significance level when moving from the ordered probit model [column (i)] to the hopit model [column (ii)]. Education has a positive effect which is significant in the ordered porbit specification but smaller and insignificant in the hopit specification. Van Praag and Ferrer-i-Carbonell (2008) find a negative effect of years of education, but they explicitly control for the positive effect of permanent income. We cannot do this (since we do not have panel data) so that in our case, the effect of education may be a combination of a (possibly negative) direct effect and a positive effect through permanent income. Some other variables are significant at the $10 \%$ level in one specification but not in the other one. But the general conclusion is that the differences between the two sets of estimates for the parameters of main interest in Table 5 are quite modest compared to the differences in the country specific effects in Table 4. Correcting for response scale differences mainly affects the comparison across countries and much less influences conclusions about differences in quality of social contacts between socioeconomic groups within a given country.

\section{Counterfactuals}

In this section, we simulate counterfactual distributions of satisfaction with social contacts using the parameter estimates of the most extensive specification of the hopit model [column (viii) in Table 4 and all columns except the first one in Table 5]. First, we simulate satisfaction levels for all respondents using their estimated actual thresholds. The resulting distributions in all countries, given in detail in Table 8 in the "Appendix" and illustrated in Fig. 1 are similar to the observed distributions in the data, indicating that the model is able to reproduce the cross country differences in reported satisfaction.

To illustrate the consequences of cross-country differences in thresholds, the second simulation produces the hypothetical ("counterfactual") distribution of satisfaction in each 
Fig. 1 Simulated distribution of reported satisfaction with social contacts by country using actual response scales (countries ordered by percentage very satisfied or satisfied)

Fig. 2 Simulated distribution of satisfaction with social contacts using German thresholds (countries ordered by percentage very satisfied or satisfied)
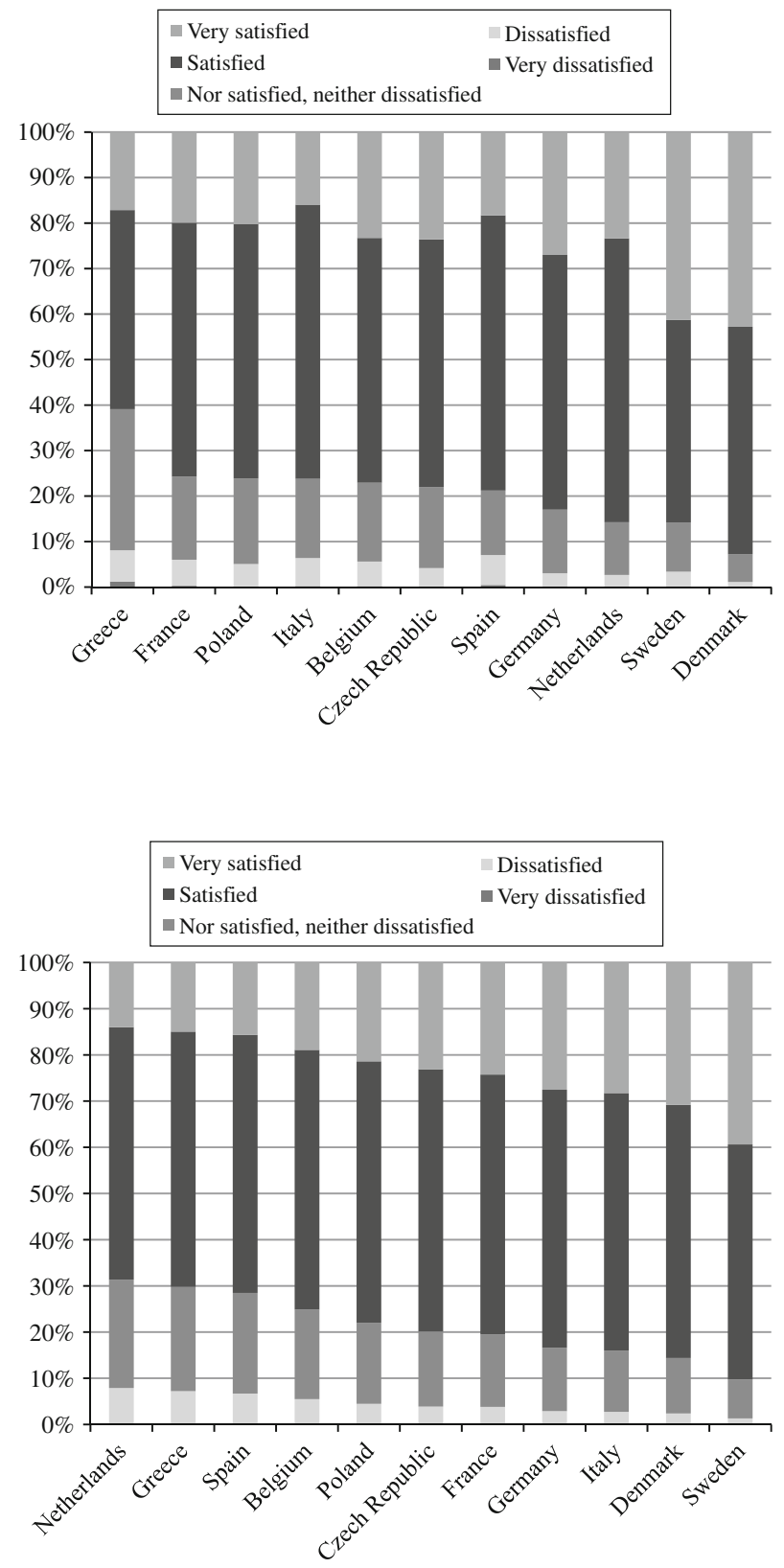

country using the thresholds that the average respondent in the benchmark country (Germany) ${ }^{4}$ would use (instead of their actual threshold). This simulation shows the differences across countries that remain when cross-cultural differences in evaluation norms

\footnotetext{
${ }^{4}$ For each respondent, we replace the thresholds by thresholds of the average German respondent (i.e. with the average individual characteristics of the German sample).
} 
(thresholds) are eliminated, since all respondents now use German thresholds. The results are presented in Table 9 in the "Appendix" and are illustrated in Fig. 2. They are generally in line with the estimates in Table 4.

Denmark and Sweden perform quite well and are the top two countries, both before and after correcting for response scale differences, but the correction reverses their ranking. This is because the Danes tend to give much more positive evaluations than the Swedes, and correcting for this makes the Danes less well off. The position of the Netherlands deteriorates substantially when controlling for response scale differences, because of the positive evaluation norms used by Dutch respondents in this domain, as already seen in Tables 4 and 5 . While $85 \%$ of the Dutch are satisfied or very satisfied with social contacts when using their own reporting thresholds (3rd in the country ranking), this would fall to $69 \%$ when they would use the German benchmark thresholds (11th and last in the ranking). In contrast, the positions of Italy and France substantially improve due to the correction. Greece seems hopelessly behind the rest of the countries when their reports are taken at face value, but this is partly due to their critical use of response scales. The percentage of satisfied or very satisfied Greek respondents rises from $62 \%$ with Greek scales to $70 \%$ with German scales, putting Greece just before the Netherlands at 10th place in the country ranking.

Taking all countries together and considering the country ranking based upon the percentage satisfied or very satisfied, we find that the overall picture changes substantially due to the correction for response scale differences. Before correction, Denmark is clearly ranked first, followed at some distance by Sweden, the Netherlands and Germany. Then come all the other countries except Greece, and Greece is way behind everyone else. After the corrections, Sweden clearly ranks first, followed by Denmark, Italy and Germany. Next comes an "average" group with France, the Czech Republic, Poland, and Belgium. Finally, Spain, Greece, and finally, the Netherlands, form the group of worst performing countries. Some of these corrections are similar to those in quite different domains such as job satisfaction (Kristensen and Johansson 2008), such as the improvement of the French and the worsening of the Danish position, but others seem specific to the domain of social contacts considered here, such as the deterioration of the Dutch. As illustrated in Figs. 1 and 2, the country rankings are somewhat different if other cut-offs are used, but the main conclusion remains the same: correcting for response scale differences has a large effect.

\section{Conclusion}

This paper has analyzed an important aspect of well-being among individuals of ages 50 and older in eleven European countries: satisfaction with social contacts. Older individuals in Europe generally report that they are satisfied with their social contacts, but there are substantial differences across European countries. In Greece, individuals report by far the lowest satisfaction level, while Denmark and Sweden are on the other end of the spectrum. The main result of our analysis is that differences in response scales explain an important part of these cross-country differences. Correcting for the differences in response styles, using a model that exploits the information in anchoring vignettes on satisfaction with social contacts, substantially affects the cross-country ranking. Denmark changes from the first to the second place after Sweden but more strikingly, the Netherlands drops from the third best to the very last position. In contrast, Italy and France climb from among 
the weakest performing countries to third one once differential item functioning is controlled for.

Correcting for response scale differences has much less effect on the estimates of what drives within country differences in satisfaction with social contacts between sociodemographic groups. For example, it does not affect the conclusion that income, but particularly contacts with children and non-professional activities play an important role in satisfaction with social contacts.

The implications for public policy may seem less clear than for other domains like income satisfaction or job satisfaction. For such domains, the typical way in which policy makers will use international comparisons is to praise their existing policies (in case their country performs well) or to motivate the need for policy change and to learn from the policies in other countries (in case other countries perform better). For income and job satisfaction, this applies to policies concerning income taxes, social security benefits for unemployed or disabled workers and old age state pensions, policies concerning occupational pensions and other (tax-favored) retirement savings, etc. Although numerous studies have shown that social contacts play an important role in contributing to well-being, protecting against mental health problems, and preventing social exclusion, policies directly aimed at improving the quality and quantity of social contacts are discussed much less often. A notable exception is the work by Findlay (2003), listing various policies aimed at preventing social exclusion and loneliness of the elderly and evaluating their effectiveness at the national as well as the local community level. The results of the current paper also suggest that stimulating participation in activities, for example through social or sport clubs or the church is an effective way of improving social contacts. Most of all, however, it warns against comparing national policies on the basis of reported satisfaction levels, because the cross-country differences in the reports are strongly affected by the cultural factors driving the way in which people in different countries answer this type of questions. This is a result that has been found repeatedly for other domains of life (health, work disability, job satisfaction, income satisfaction, etc.) but is new for the domain of social contacts.

Acknowledgments We are grateful to two anonymous referees, Martin Humburg, Hendrik Jürges, Olga Skriabikova, Teresa Bago d'Uva, and other participants of the final COMPARE conference in Brussels for useful comments. This paper uses data from SHARE release 2.3.0, as of November 13th 2009. SHARE data collection in 2004-2007 was primarily funded by the European Commission through its 5th and 6th framework programmes (project numbers QLK6-CT-2001- 00360; RII-CT- 2006-062193; CIT5-CT-2005028857). Additional funding by the US National Institute on Aging (grant numbers U01 AG09740-13S2; P01 AG005842; P01 AG08291; P30 AG12815; Y1-AG-4553-01; OGHA 04-064; R21 AG025169) as well as by various national sources is gratefully acknowledged (see http://www.share-project.org for a full list of funding institutions).

Open Access This article is distributed under the terms of the Creative Commons Attribution Noncommercial License which permits any noncommercial use, distribution, and reproduction in any medium, provided the original author(s) and source are credited.

\section{Appendix}

See Tables 6, 7, 8, and 9 . 


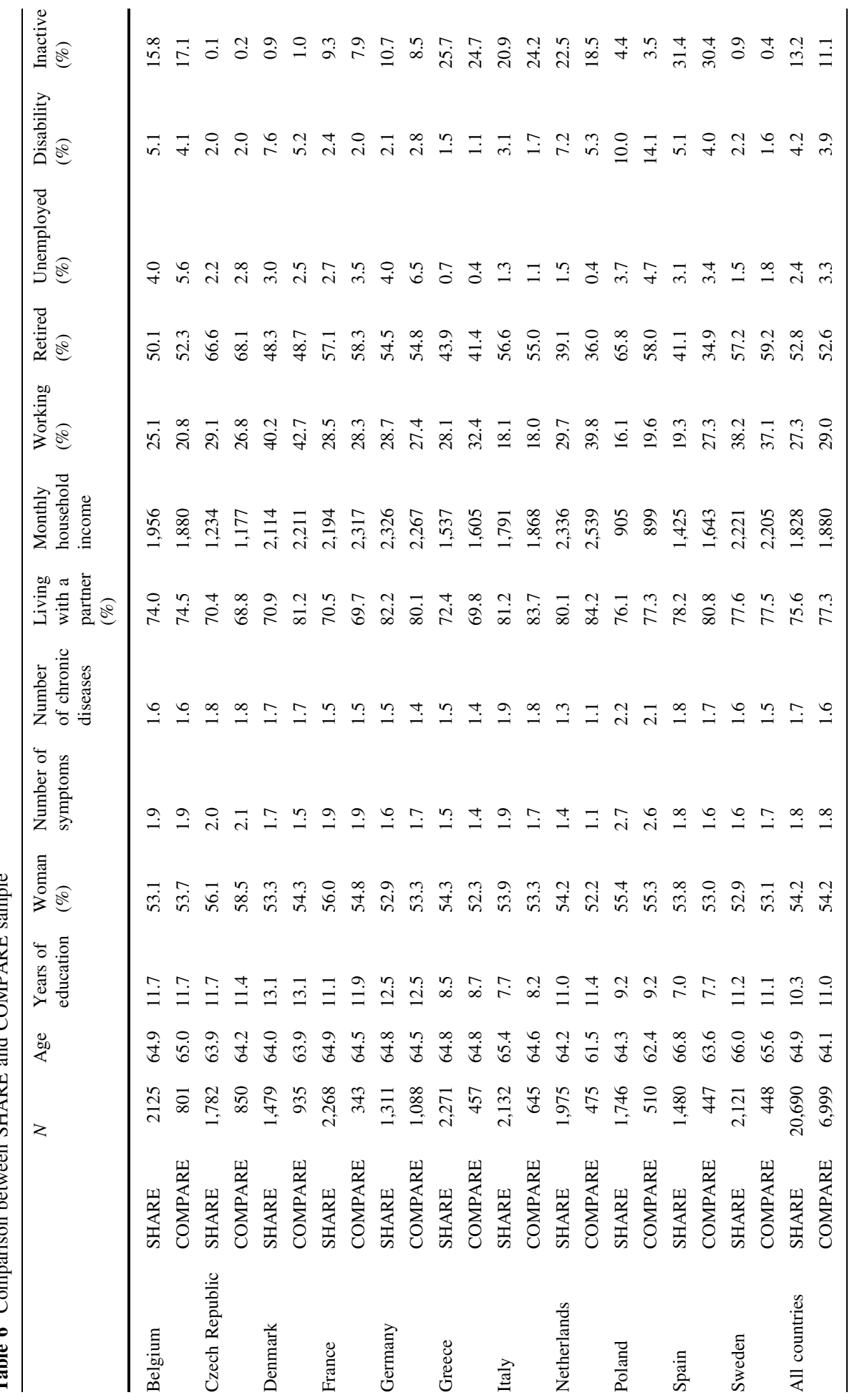




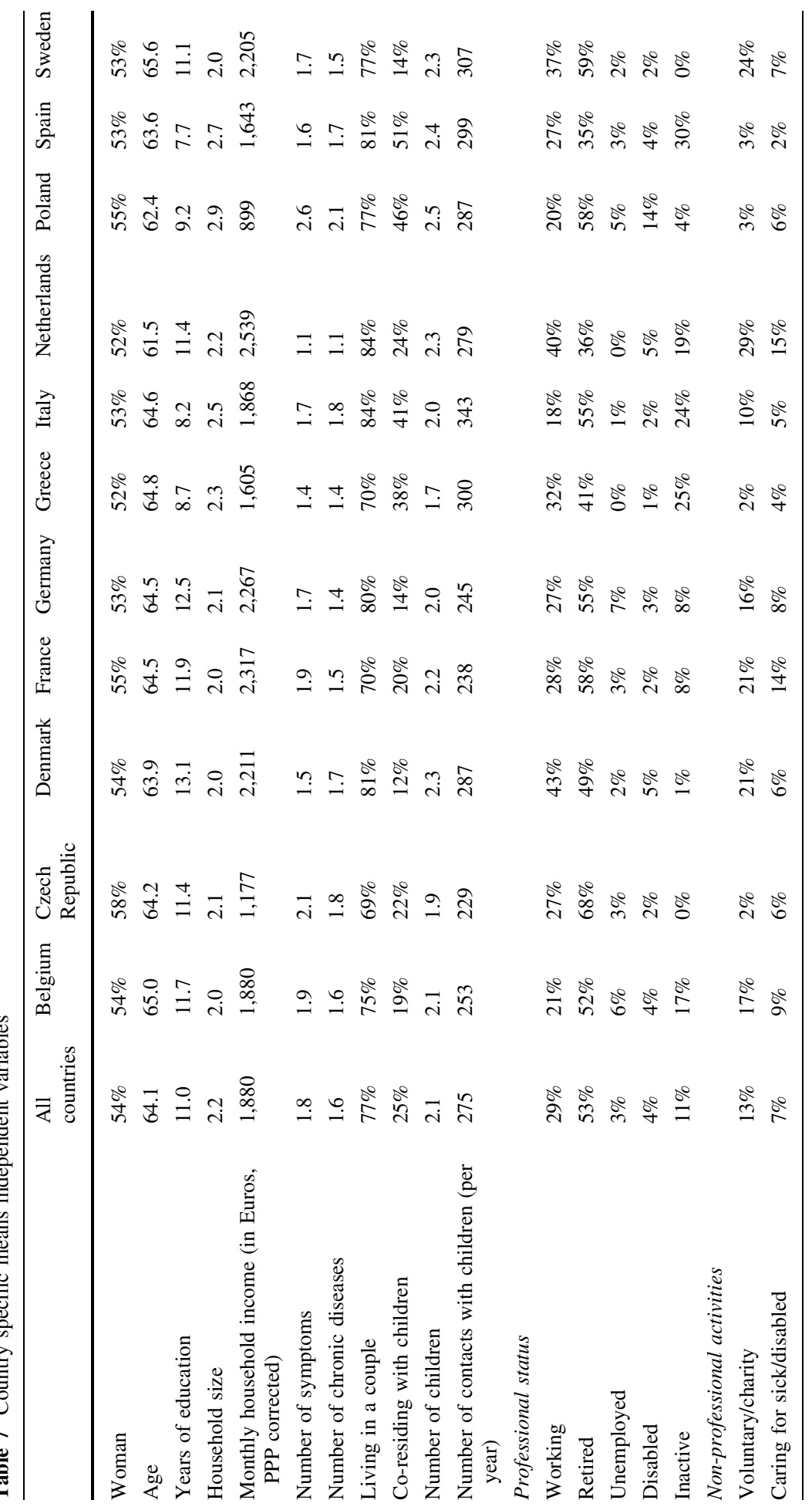




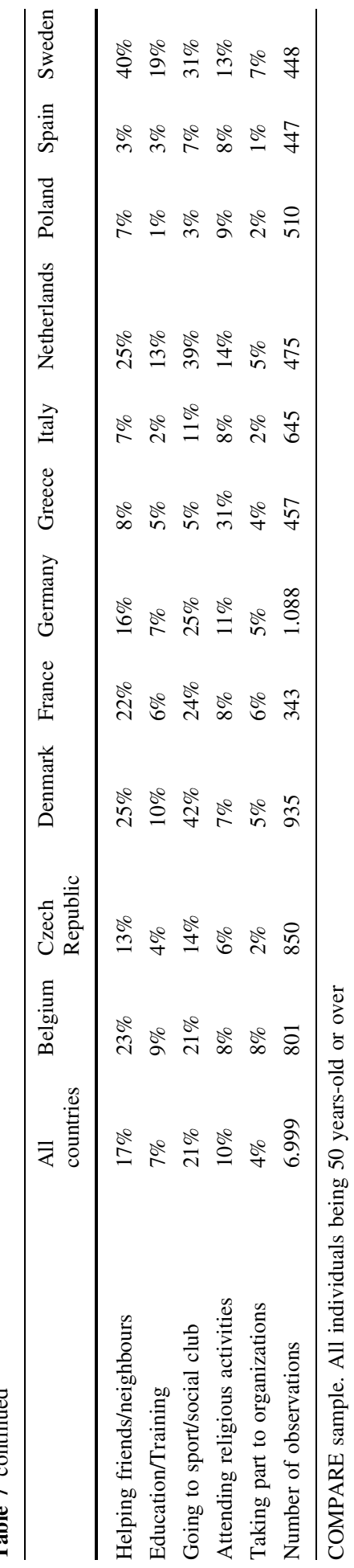


Table 8 Predicted distribution of satisfaction with social contacts among the 50+ Europeans using actual thresholds

\begin{tabular}{llllll}
\hline & $\begin{array}{l}\text { Very } \\
\text { dissatisfied } \\
\text { (in percentage) }\end{array}$ & $\begin{array}{l}\text { Dissatisfied } \\
\text { (in percentage) }\end{array}$ & $\begin{array}{l}\text { Nor satisfied, } \\
\text { neither dissatisfied } \\
\text { (in percentage) }\end{array}$ & $\begin{array}{l}\text { Satisfied } \\
\text { (in percentage) }\end{array}$ & $\begin{array}{l}\text { Very satisfied } \\
\text { (in percentage) }\end{array}$ \\
\hline Sweden & 0 & 3 & 11 & 45 & 41 \\
Denmark & 0 & 1 & 6 & 50 & 43 \\
Netherlands & 0 & 3 & 12 & 62 & 23 \\
Germany & 0 & 3 & 14 & 56 & 27 \\
Belgium & 0 & 5 & 17 & 54 & 23 \\
France & 0 & 6 & 18 & 56 & 20 \\
Poland & 0 & 5 & 19 & 56 & 20 \\
Czech Republic & 0 & 4 & 18 & 54 & 24 \\
Italy & 0 & 6 & 17 & 60 & 16 \\
Spain & 0 & 7 & 14 & 60 & 18 \\
Greece & 1 & 7 & 31 & 44 & 17 \\
All countries & 0 & 4 & 15 & 54 & 26 \\
\hline
\end{tabular}

Table 9 Predicted distribution of satisfaction with social contacts among the 50+ Europeans using German thresholds

\begin{tabular}{llllll}
\hline & $\begin{array}{l}\text { Very } \\
\text { dissatisfied } \\
\text { (in percentage) }\end{array}$ & $\begin{array}{l}\text { Dissatisfied } \\
\text { (in percentage) }\end{array}$ & $\begin{array}{l}\text { Nor satisfied, } \\
\text { neither dissatisfied } \\
\text { (in percentage) }\end{array}$ & $\begin{array}{l}\text { Satisfied } \\
\text { (in percentage) }\end{array}$ & $\begin{array}{l}\text { Very satisfied } \\
\text { (in percentage) }\end{array}$ \\
\hline Sweden & 0 & 1 & 8 & 51 & 39 \\
Denmark & 0 & 2 & 12 & 55 & 31 \\
Netherlands & 0 & 8 & 23 & 55 & 14 \\
Germany & 0 & 3 & 14 & 56 & 28 \\
Belgium & 0 & 5 & 19 & 56 & 19 \\
France & 0 & 4 & 16 & 56 & 24 \\
Poland & 0 & 4 & 18 & 57 & 21 \\
Czech Republic & 0 & 4 & 16 & 57 & 23 \\
Italy & 0 & 3 & 13 & 56 & 28 \\
Spain & 0 & 7 & 22 & 56 & 16 \\
Greece & 0 & 7 & 23 & 55 & 15 \\
All countries & 0 & 4 & 16 & 55 & 24 \\
\hline
\end{tabular}

\section{References}

Bago d'Uva, T., Van Doorslaer, E., Lindeboom, M., \& O'Donnell, O. (2008). Does reporting heterogeneity bias the measurement of health disparities? Health Economics, 17(3), 351-375.

Börsch-Supan, A., Brugiavini, A., Jürges, H., Kapteyn, A., Mackenbach, J., Siegrist, J., et al. (2008). Health, ageing and retirement in Europe (2004-2007). Mannheim: MEA.

Börsch-Supan, A., Brugiavini, A., Jürges, H., Mackenbach, J., Siegrist, J., \& Weber, G. (2005). Health, ageing and retirement in Europe-First results from the survey of health, ageing and retirement in Europe. Mannheim: MEA.

Farquhar, M. (1995). Elderly people's definitions of quality of life. Social Science and Medicine, 41(10), $1439-1446$. 
Findlay, R. A. (2003). Interventions to reduce social isolation amongst older people: Where is the evidence? Ageing and Society, 23, 647-658.

Frijters, P. (2000). Do individuals try to maximize general satisfaction? Journal of Economic Psychology, $21,281-304$.

Gabriel, Z., \& Bowling, A. (2004). Quality of life from the perspectives of older people. Ageing and Society, 24, 675-691.

González, M., Casas, F., \& Coenders, G. (2007). A complexity approach to psychological well-being in adolescence: Major strengths and methodological issues. Social Indicators Research, 80, 267-295.

Helliwell, J. F., Barrington-Leigh, C., Harris, A., \& Huang, H. (2010). International evidence on the social context of well-being. In E. Diener, J. F. Helliwell, \& D. Kahneman (Eds.), International differences in well-being (pp. 291-325). Oxford: Oxford University Press.

Helliwell, J. F., \& Putnam, R. D. (2004). The social context of well-being. Philosophical Transactions of the Royal Society of London B, 359, 1435-1446.

Holmén, K., \& Furukowa, H. (2002). Loneliness, health and social network among elderly people-A follow-up study. Archives of Gerontology and Geriatrics, 35, 261-274.

Kapteyn, A., Smith, J. P., \& Van Soest, A. (2007). Vignettes and self-reports of work disability in the US and the Netherlands. American Economic Review, 97(1), 461-473.

Kapteyn, A., Smith, J. P., \& Van Soest, A. (2010). Life satisfaction. In E. Diener, J. E. Helliwell, \& D. Kahneman (Eds.), International differences in well-being (pp. 70-104). Oxford: Oxford University Press.

King, G., Murray, C., Salomon, J., \& Tandon, A. (2004). Enhancing the validity and cross-cultural comparability of measurement in survey research. American Political Science Review, 98(1), 567-583.

Kristensen, N., \& Johansson, E. (2008). New evidence on cross-country differences in job satisfaction using anchoring vignettes. Labour Economics, 15, 96-117.

Melchior, M., Niedhammer, I., Berkman, L., \& Goldberg, M. (2003). Do psychosocial work factors and social relations exert independent effects on sickness absence? A six year prospective study of the GAZEL cohort. Journal of Epidemiology and Community Health, 57, 285-293.

Motel-Klingebiel, A., von Kondratowitz, H. J., \& Tesch-Römer, C. (2004). Social inequality in the later life: Cross-national comparison of quality of life. European Journal of Ageing, 1, 6-14.

Palomar Lever, J. (2004). Poverty and subjective well-being in Mexico. Social Indicators Research, 68, $1-33$.

Pollack, G. E., \& von dem Knesebeck, O. (2004). Social capital and health among the aged: Comparisons between the United States and Germany. Health and Place, 10, 383-391.

Powdthavee, N. (2008). Putting a price tag on friends, relatives, and neighbours: Using surveys of life satisfaction to value social relationships. Journal of Socio-Economics, 37, 1459-1480.

Rasulo, D., Christensen, K., \& Tomassini, C. (2005). The influence of social relations on mortality in later life: A study of elderly Danish twins. The Gerontologist, 45(3), 601-608.

Rice, N., Robone, S., \& Smith, P. C. (2010). International comparison of public sector performance: The use of anchoring vignettes to adjust self-reported data. Evaluation, 16(1), 81-101.

Rojas, M. (2006). Life satisfaction and satisfaction in domains of life: Is it a simple relationship? Journal of Happiness Studies, 7, 467-497.

Van Praag, B., \& Ferrer-i-Carbonell, A. (2008). Happiness quantified-A satisfaction calculus approach. Oxford: Oxford University Press.

Van Praag, B., Frijters, P., \& Ferrer-i-Carbonell, A. (2003). The anatomy of subjective well-being. Journal of Economic Behavior \& Organization, 51, 29-49.

Van Soest, A. (2008). Enhancing international comparability using anchoring vignettes. In: A. Börsch-Supan et al. (Eds.), Health, ageing and retirement in Europe (2004-2007) (pp. 351-355). Mannheim: MEA.

Van Soest, A., Delaney, L., Harmon, C., Kapteyn, A., \& Smith, J. P. (2011). Validating the use of vignettes for subjective threshold scales. Journal of the Royal Statistical Society Series A, forthcoming.

Wang, H.-X., Karp, A., Winblad, B., \& Fratiglioni, L. (2002). Late-life engagement in social and leisure activities is associated with a decreased risk of dementia: A longitudinal study from the Kungsholmen project. American Journal of Epidemiology, 155(12), 1081-1087. 